\title{
Concrete confinement with TRM versus FRP jackets at elevated temperatures
}

\author{
G. Cerniauskas $\cdot$ Z. Tetta $\cdot$ D. A. Bournas $(\mathbb{D} \cdot$ L. A. Bisby
}

Received: 14 December 2019/Accepted: 10 May 2020/Published online: 20 May 2020

(C) The Author(s) 2020

\begin{abstract}
Despite the clear cost, ease of installation, and construction schedule advantages of confinement of concrete structural elements with fibre-reinforced polymers (FRPs) for strength and deformability enhancement, concerns as to their performance at elevated temperature, or in fire, remain. The results of a series of elevated temperature experiments on FRP and textile reinforced mortar (TRM) strengthening systems for confinement of circular concrete columns are presented. The behaviour and effectiveness of the respective confining systems is studied up to temperatures of $400{ }^{\circ} \mathrm{C}$. A total of 24 concrete cylinders were wrapped in the hoop direction with different amounts of FRP or TRM, heated to steady-state temperatures between 20 and $400{ }^{\circ} \mathrm{C}$, and loaded to failure in
\end{abstract}

G. Cerniauskas · L. A. Bisby

Institute for Infrastructure and Environment, School of Engineering, The University of Edinburgh, Edinburgh, UK

e-mail: luke.bisby@ed.ac.uk

\section{Z. Tetta}

The University of Nottingham, Nottingham, UK

Present Address:

Z. Tetta

WSP Engineering Consulting, London, UK

D. A. Bournas $(\square)$

European Commission, Joint Research Centre (JRC), Ispra, Italy

e-mail: Dionysios.BOURNAS@ec.europa.eu concentric axial compression under a steady-state thermal regime. The results indicate that the effectiveness of the FRP confining system bonded with epoxy decreased considerably, but did not vanish, with increasing temperatures, in particular within the region of the glass transition temperature of the epoxy resin/adhesive. Conversely, the TRM confining system, bonded with inorganic mortar rather than epoxy, demonstrated superior performance than the FRP confining system at $400{ }^{\circ} \mathrm{C}$ as compared against tests performed at ambient temperature.

Keywords FRP - Textile reinforced mortar - TRM Strengthening $\cdot$ High temperature $\cdot$ Fire $\cdot$ Confinement

\section{Introduction and background}

A popular application of fibre reinforced polymers (FRPs) is strengthening concrete columns by confinement with FRP in the hoop direction [1]. However, the performance of FRP systems at elevated temperatures is potentially problematic since much of their strength, stiffness, and bond properties are lost at temperatures that are rapidly exceeded in building fires [2]. Carbon fibres used in FRP systems may be capable of resisting temperatures of more than $800{ }^{\circ} \mathrm{C}$; however, epoxies used to bond the fibres and adhere FRP systems to concrete lose a considerable proportion of their 
mechanical properties at temperatures as low as $60-82{ }^{\circ} \mathrm{C}$ [3]. These reductions in mechanical properties can be expected in the region of the epoxy's glass transition temperature $\left(T_{g}\right)$ as it changes from hard and brittle to soft and plastic. Testing has been carried out previously to investigate the performance of FRP confining systems for concrete columns during standard fire exposures (e.g. [4]) and during both transient and steady-state heating to elevated temperatures [5]. This testing has shown that considerable (about 50\%) loss of effectiveness of the FRP strengthening system occurred at temperatures as low as $15^{\circ} \mathrm{C}$ below the $T_{g}$ of the epoxy adhesive, which is thought to be due to reductions in the tensile strength and stiffness of the FRP wraps at these temperatures.

To alleviate the reduced effectiveness of FRP systems at elevated temperatures, a novel composite material, namely textile-reinforced mortar (TRM) has been proposed during the last decade for strengthening concrete elements [6]. TRM combines advanced fibres in form of textiles (with open-mesh configuration) with inorganic matrices, such as cement-based mortars. The same class of materials is also referred to in the literature as FRCM (e.g. [7]). The effectiveness of TRM as a strengthening material has been investigated in a number of studies (i.e. [8-13]) and found to be comparable to FRP systems in many respects. TRM confinement was very effective in enhancing the strength and deformability of concrete and RC columns [14], but also their deformation capacity under seismic loading [15, 16]. Moreover TRM jacketing has been recently combined with thermal insulation materials for the concurrent seismic and energy retrofitting of the building envelopes [17-20].

TRM composites appear to be non-combustible nor flammable and are expected to outperform FRPs at high temperatures. Nonetheless, the behaviour of TRM versus FRP systems at elevated temperature or fire has not been investigated yet sufficiently, due to the experimental difficulties that exist in applying simultaneously loading and elevated temperatures or fire to the tested specimens. Hence, the majority of studies identified in the literature were concentrated on either the mechanical (tensile stress-strain) behaviour of TRM composites, or on examining the residual capacity of TRM as a strengthening material of $\mathrm{RC} /$ masonry structural elements (e.g. [9, 20-28]).
There are only a few studies reported in the literature on TRM versus FRP as strengthening materials at high temperature, namely those of Bisby et al. [29], Tetta and Bournas [30] and Raoof and Bournas [31, 32]. Bisby et al. [29] undertook flexural strengthening of RC beams. Both un-retrofitted and strengthened beams were tested up to failure at ambient temperature, and their counterpart specimens were tested under sustained load while being exposed to increasing elevated temperature. In specimens tested at high temperature, the critical-anchorage zones were kept cool (presuming that debonding of heated anchorage zones is prevented through insulation or by mechanical means). Tetta and Bournas [30] investigated the performance of TRM vs FRP at high temperature in shear strengthening of medium and full-scale RC beams, concluding that TRM is much more effective than FRP in increasing shear capacity of RC beams subjected to various high temperatures $\left(100{ }^{\circ} \mathrm{C}, 150{ }^{\circ} \mathrm{C}\right.$, and $\left.250{ }^{\circ} \mathrm{C}\right)$. Raoof and Bournas [31] investigated the bond performance between the TRM vs FRP and concrete interfaces at ambient and high temperatures. In steady state tests, TRM specimens maintained an average of $85 \%$ of their ambient bond strength up to $400{ }^{\circ} \mathrm{C}$, whereas the corresponding value for FRP specimens was only $17 \%$ at $150{ }^{\circ} \mathrm{C}$. In transient test condition, TRM also outperformed over FRP in terms of both the time they maintained the applied load and the temperature reached before failure. Finally, Raoof and Bournas [32] explored the flexural behaviour of RC beams strengthened with TRM and FRP composites at ambient and high temperatures. TRM maintained an average effectiveness of $55 \%$, compared to its effectiveness at $20{ }^{\circ} \mathrm{C}$, contrary to FRP which totally lost its effectiveness when subjected at high temperature.

In an effort to develop strengthening systems with enhanced performance at elevated temperatures, this paper investigates, for the first time, the performance and effectiveness of both FRP and TRM confining materials of concrete at elevated temperatures, such as would be experienced during a fire, when the confining system is active under sustained load; this was done by testing concrete cylinders with different amounts of FRP or TRM confinement at various temperatures. The main objective was to develop an understanding of the confining mechanisms at elevated temperature and to suggest defensible limiting temperatures for FRP and TRM strengthening systems in fire. 


\section{Experimental program}

The main objective of the experimental program was to provide a better understanding on the effectiveness of TRM versus FRP confinement of concrete at ambient and elevated temperatures. The investigation was carried out on cylindrical specimens. The investigated parameters considered include, the use of inorganic mortar versus resin-based matrix material for the textile reinforcement (TRM vs. FRP), the number of textile layers (one or three) and the increase of temperature (from ambient to $400{ }^{\circ} \mathrm{C}$, with the tests performed under a steady-state thermal regime at elevated temperature).

Thirty tests were performed on normal strength concrete cylinders that were loaded at both ambient and elevated temperatures. All tests were performed under a steady state thermal regime. Details of the experimental program are given in Table 1 . All tests were on $100 \mathrm{~mm}$ diameter, $200 \mathrm{~mm}$ tall concrete cylinders; this was chosen as it allowed test specimens to fit within a bespoke environmental chamber fitted within a $600 \mathrm{kN}$ materials testing frame. All cylinders were cast in groups of ten in three batches using the same concrete mix design. The compressive strength of concrete was determined firstly from three $150 \mathrm{~mm}$ cubes taken during casting of the cylinders. The resulting value for the 28-day average compressive strength was $25 \mathrm{MPa}$ with a standard deviation of 1.7 MPa. Parameters varied within the testing program included the following.

\subsection{Type and amount of confinement}

Six cylinders were tested without confinement to determine the unconfined concrete properties and to determine the reductions in concrete properties caused by heating to the maximum exposure temperature used $\left(400{ }^{\circ} \mathrm{C}\right)$. Twelve cylinders were wrapped with FRP (six with a single layer and six with three continuous layers), whereas twelve additional cylinders were wrapped with TRM (six with a single layer and six with three continuous layers). Table 1 summarizes the details of all tested specimens.

The same reinforcement was used in both TRM and FRP systems. This reinforcement comprised a textile with equal quantity of high-strength carbon fibres in two orthogonal directions, as shown in Fig. 1a. The weight of the textile was $220 \mathrm{~g} / \mathrm{m}^{2}$, whereas its nominal thickness (based on the equivalent smeared distribution of fibres) was $0.062 \mathrm{~mm}$. According to the manufacturer datasheets the tensile strength and the modulus of elasticity of the carbon fibres were $4800 \mathrm{MPa}$ and 225 $\mathrm{GPa}$, respectively. It should be noted however, that the use of bi-directional textiles comprising equal quantity of fibres in two orthogonal directions makes little sense in practical confinement applications where the fibres in the longitudinal direction are not needed. In such cases the carbon longitudinal fibres could be replaced with cheap (e.g. polypropylene or glass) and lighter fibres, should the manufacturing of such hybrid textiles becomes affordable in the future.

For the specimens receiving mortar as binding material an inorganic binder was used, consisting of Portland cement and polymers at a quite large ratio of $8: 1$ by weight, for achieving high tensile strength. The water-binder ratio in the mortar was $0.23: 1$ by weight and in combination with the fine grained sand $(0-0.4 \mathrm{~mm})$ resulted in plastic consistency and excellent workability. The strength properties of the mortar (average values of three specimens) was obtained experimentally using prisms of $40 \times 40 \times 160 \mathrm{~mm}$ dimensions, according to the EN 1015-11 [33]. The 28-day average mortar's compressive and flexural strength were 26.9 MPa and 8.64 MPa, respectively, at ambient temperature. Mortar prisms were also tested at various elevated temperatures. The prisms were fixed in the furnace, heated up to the desired temperature, kept for one hour at this temperature, and then tested according to the EN 1015-11 specifications. This procedure was repeated for various temperatures, and Fig. 1b illustrates the mortar flexural and compressive strength versus temperature curve. For the specimens receiving epoxy adhesive as binding material, a commercial adhesive (two-part epoxy resin Sikadur 330, with a mixing ratio $4: 1$ by weight) was used with an elastic modulus of $3.8 \mathrm{GPa}$ and a tensile strength of $30 \mathrm{MPa}$ (according to the manufacturer datasheets). It is noted that, in general the temperature behavior of the adhesive is strongly affected by the type of epoxy under consideration (e.g. $[34,35])$. Tests for the epoxy used are presented in the following section.

For FRP-jacketed specimens the first textile layer was applied on the top of the first resin layer and was then impregnated in situ with resin using a plastic roll. Special care was taken to ensure the full impregnation of the textile fibres with resin. When three textile 
Table 1 Details of the experimental program

\begin{tabular}{|c|c|c|c|c|}
\hline No. & Wrapping & $\begin{array}{l}\text { Matrix/ } \\
\text { adhesive }\end{array}$ & $\begin{array}{l}\text { Exposure temp. } \\
\left({ }^{\circ} \mathrm{C}\right)\end{array}$ & Comments \\
\hline $\begin{array}{l}1 \\
2\end{array}$ & \multirow[t]{5}{*}{-} & \multirow[t]{5}{*}{-} & 20 & $\begin{array}{l}\text { Control tests on unconfined concrete at ambient (with repeat } \\
\text { test) }\end{array}$ \\
\hline 3 & & & 100 & Control tests on unconfined concrete at elevated temperature \\
\hline 4 & & & 150 & \\
\hline 5 & & & 200 & \\
\hline 6 & & & 400 & \\
\hline 7 & \multirow[t]{6}{*}{ Single layer of FRP } & \multirow[t]{6}{*}{ Epoxy } & 20 & FRP confined concrete at ambient \\
\hline 8 & & & 80 & Temperatures in the range of $T_{g}{ }^{*}$ \\
\hline 9 & & & 100 & \\
\hline 10 & & & 150 & Temperatures well above $T_{g}{ }^{*}$ \\
\hline 11 & & & 200 & \\
\hline 12 & & & 400 & -Temperature in the range of $T_{d} * *$ \\
\hline 13 & \multirow[t]{6}{*}{ Single layer of TRM } & \multirow[t]{6}{*}{ Mortar } & 20 & TRM confined concrete at ambient \\
\hline 14 & & & 100 & Single layer of TRM at various temperatures \\
\hline 15 & & & 150 & \\
\hline 16 & & & 200 & \\
\hline 17 & & & 400 & \\
\hline 18 & & & & Repeat test at $400{ }^{\circ} \mathrm{C}$ \\
\hline 19 & \multirow[t]{6}{*}{ Three layers of FRP } & \multirow[t]{6}{*}{ Epoxy } & 20 & FRP confined concrete at ambient \\
\hline 20 & & & & Repeat test at ambient \\
\hline 21 & & & 100 & Temperature in the range of $T_{g}{ }^{*}$ \\
\hline 22 & & & 150 & Temperatures well above $T_{g}{ }^{*}$ \\
\hline 23 & & & 200 & \\
\hline 24 & & & 400 & Temperature in the range of $T_{d}{ }^{* *}$ \\
\hline 25 & \multirow{6}{*}{$\begin{array}{l}\text { Three layers of } \\
\text { TRM }\end{array}$} & \multirow[t]{6}{*}{ Mortar } & 20 & TRM confined concrete at ambient \\
\hline 26 & & & 100 & Three layers of TRM at various temperatures \\
\hline 27 & & & 150 & \\
\hline 28 & & & 200 & \\
\hline 29 & & & 400 & \\
\hline 30 & & & & Repeat test at $400{ }^{\circ} \mathrm{C}$ \\
\hline
\end{tabular}

$* T_{g}$ - epoxy glass transition temperature; $* * T_{d}$-epoxy decomposition temperature

layers were to be applied, the process was repeated until the application of all the layers was completed. For TRM-jacketed specimens the mortar was applied in approximately $2 \mathrm{~mm}$-thick layers with a smooth metal trowel. After application of the first mortar layer (Fig. 2a) on the (wetted) concrete surface, the textile was applied and pressed slightly into the mortar, which protruded through all the perforations between the fibre rovings (Fig. 2b). The next mortar layer covered the textile completely, and the operation was repeated until all textile layers were applied and covered by mortar (Fig. 2c). Application of each mortar layer occurred while the previous layer was still in a fresh state. No wrap overlap was provided vertically.

\subsection{Thermal exposure}

Temperatures were chosen in the range of the $T_{g}$, as determined from Dynamic Mechanical Analysis (DMA) and the decomposition temperature $\left(T_{d}\right.$, as 


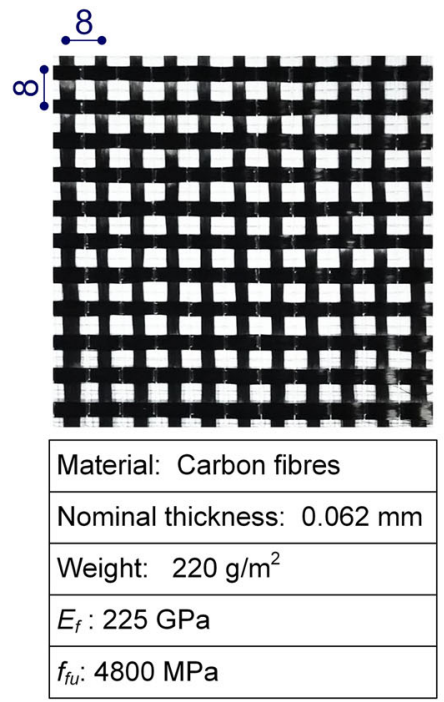

(a)

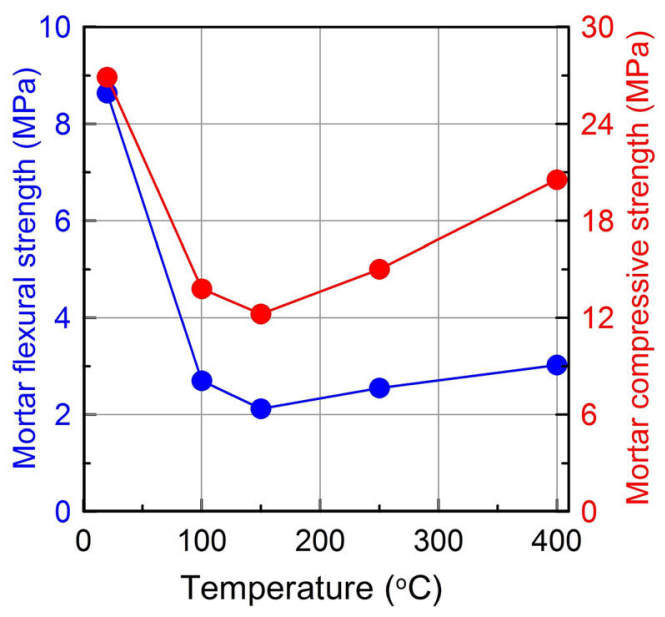

(b)

Fig. 1 a Carbon-fibre textile material used in this study; b Mortar flexural and compressive strength versus temperature curve

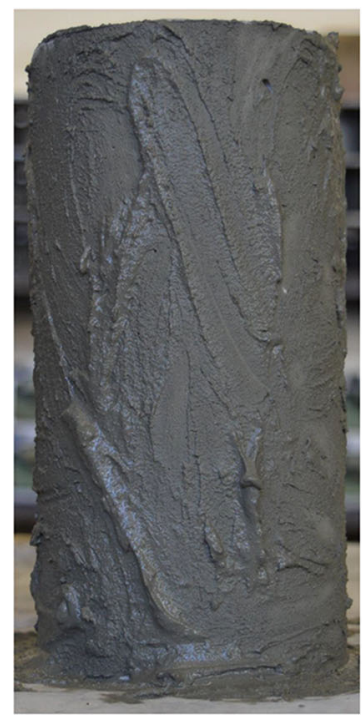

(a)

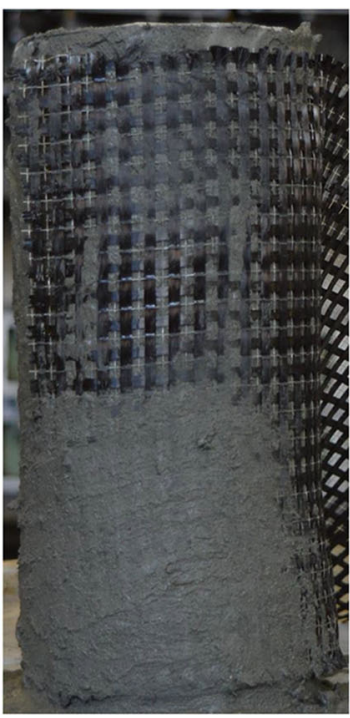

(b)

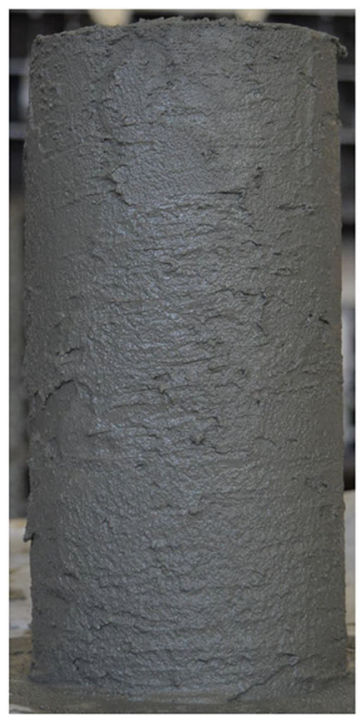

(c)

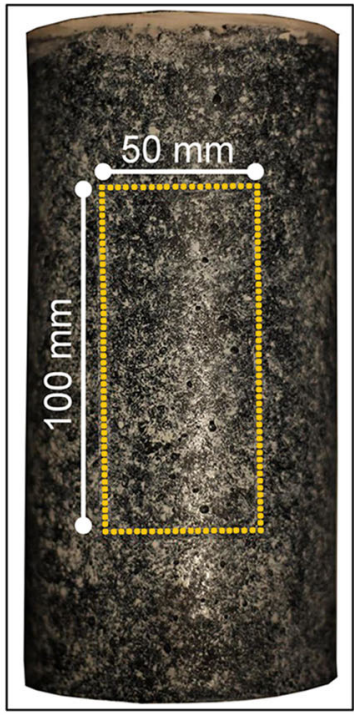

(d)

Fig. 2 a Application of the first layer of mortar; $\mathbf{b}$ application of the first layer of textile layer into the mortar; $\mathbf{c}$ application of the final layer of mortar; $\mathbf{d}$ "strain rectangle" used to calculate hoop and axial strains

determined from thermogravimetric analysis) of the epoxy adhesive. The epoxy resin used in the current study has a $T_{g}$ of $58{ }^{\circ} \mathrm{C}$ based on tan delta peak from DMA testing. Samples were heated without any applied load at a heating rate of $10^{\circ} \mathrm{C} / \mathrm{min}$ until the target temperature was reached. To assure a uniform sample temperature all samples were then held at the target testing temperature for $60 \mathrm{~min}$ before testing.
All samples were tested in an Instron 600LX testing frame with an integrated environmental chamber at a loading rate of $1 \mathrm{~mm} / \mathrm{min}$ (crosshead displacement) until failure. Axial and hoop strains were measured using image correlation analysis via digital images captured every $5 \mathrm{~s}$ during testing with post-testing analysis performed in GeoPIV software [36]. Full details of the image analysis technique have been 
presented for similar testing by Rickard et al. [5]. Temperatures were monitored during testing by a single thermocouple for gas phase temperature within the chamber (placed next to the sample) and a single thermocouple mounted on the surface of the sample at mid-height. Testing occurred at least 180 days after casting the concrete so as to ensure that the concrete had cured sufficiently to avoid explosive concrete spalling during heating (based on the experience of the authors). The test setup is shown in Fig. 3.

The monitoring area of all specimens was painted with a high contrast texturing effect using black paint with a random white speckle pattern; this was to enable the use of digital image correlation for strain measurement during testing. Strains were measured using a "strain rectangle" as shown in Fig. 2d. Hoop strains were measured as the average of 50 virtual strain gauges distributed over the height of the middle $90 \mathrm{~mm}$ of the specimens, each with a gauge length of $40 \mathrm{~mm}$. Axial strains were measured as the average of 20 virtual strain readings distributed over the width of the middle $40 \mathrm{~mm}$ of the specimens' diameter, each with a gauge length of $90 \mathrm{~mm}$. More details on this strain measurement approach can be found in Bisby et al. [1].

\subsection{Ancillary tensile tests on TRM and FRP coupons}

Three tensile TRM and FRP coupons with the geometry shown in Fig. 4a, c, respectively, were fabricated and tested to characterize the tensile behavior of the composite (TRM or FRP) materials. Uniaxial tensile testing was carried out using a $200 \mathrm{kN}$ universal testing machine at a monotonic loading rate of $0.02 \mathrm{~mm}$ per second. Two LVDTs (one on each side of the specimens) were attached to the coupons to record their axial displacement during testing, as shown in Fig. 4b, d for TRM and FRP specimens, respectively. More details on these test set-ups are given by [37].

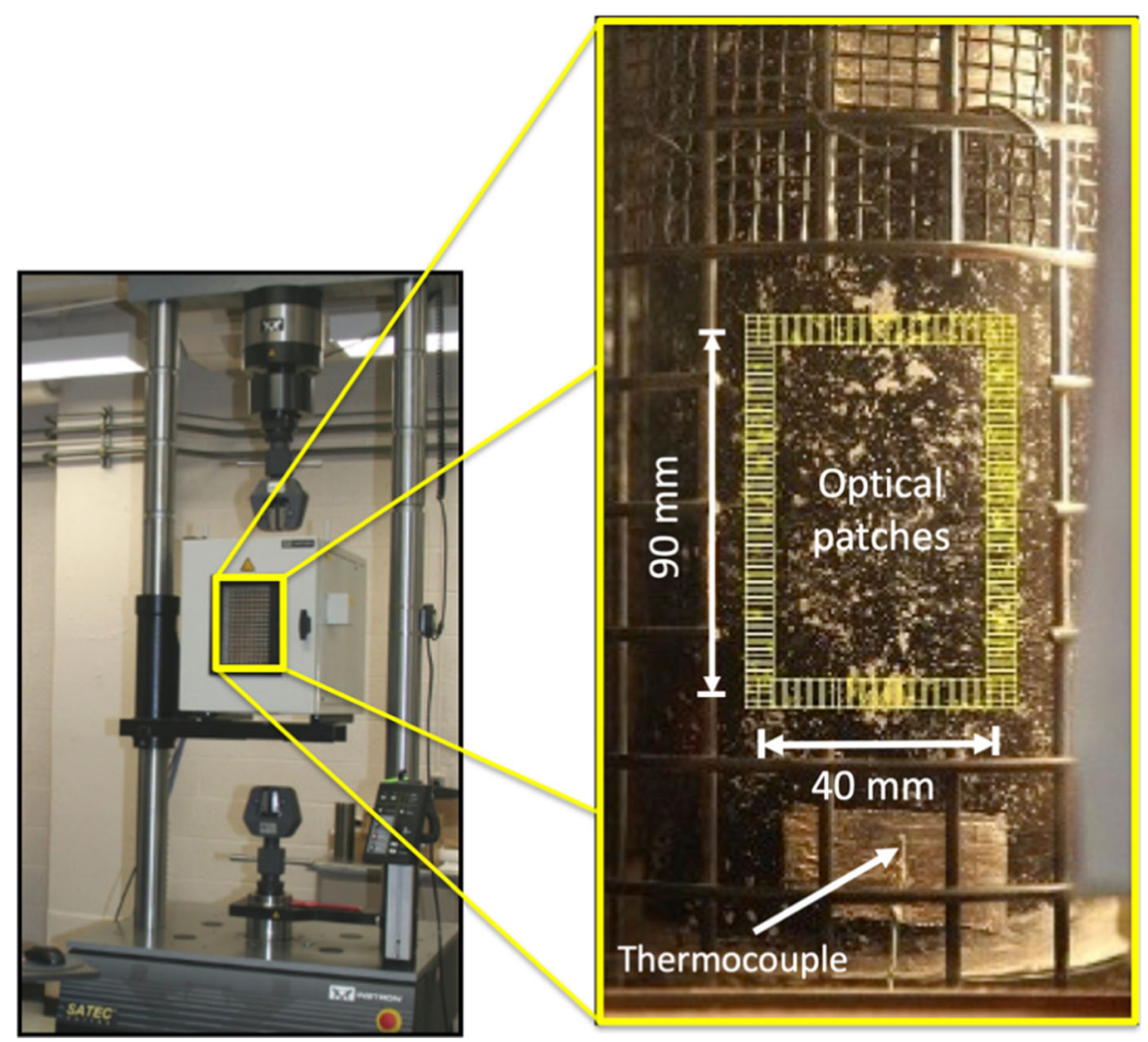

Fig. 3 Test set-up used for the compression tests at elevated temperatures

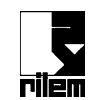




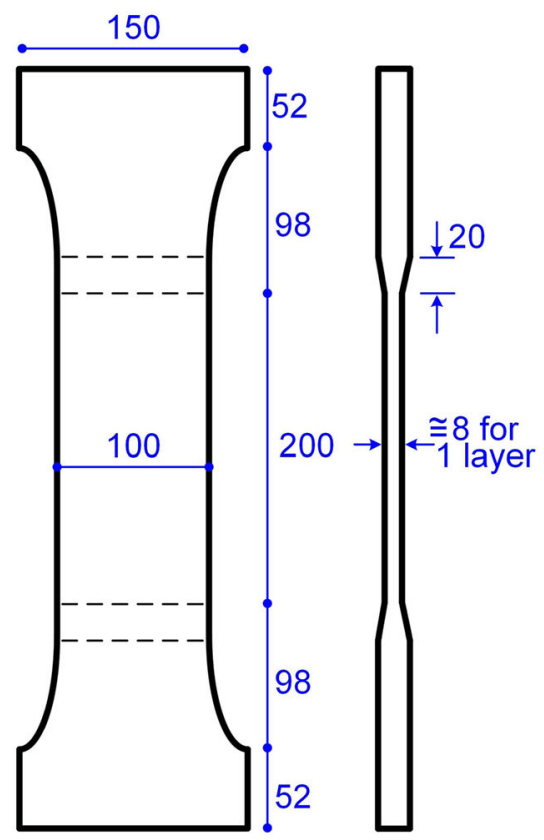

(a)

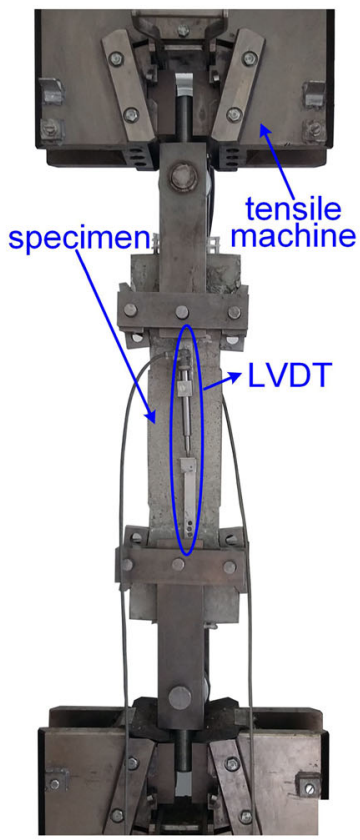

(b)

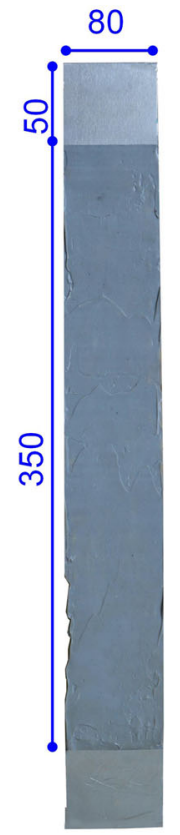

(c)

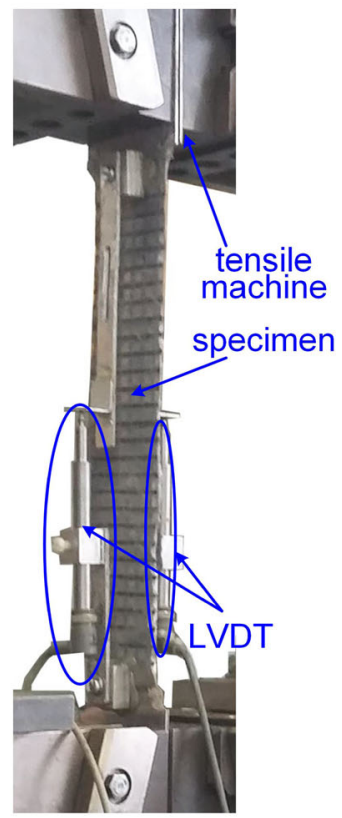

(d)

Fig. 4 a Geometry of TRM coupons; $\mathbf{b}$ test set-up for tensile testing of TRM coupons; $\mathbf{c}$ geometry of FRP coupons; $\mathbf{b}$ test set-up for tensile testing of FRP coupons

The mean values of ultimate tensile stress $\left(f_{f u}\right)$, ultimate tensile strain $\left(\varepsilon_{f u}\right)$ and the modulus of elasticity of $\left(E_{f}\right)$ for both TRM and FRP coupons are presented in Table 2 (the standard deviation is also given in parentheses).

\section{Experimental results and discussion}

Summary plots showing the results of all tests listed in Table 1 are given in Fig. 5, and numerical summaries of the tests are presented in Table 3. They include: the wrapping configuration for each specimen; the target temperature to which the sample was exposed during testing; both air and surface temperature at failure; the peak load; the peak stress, $f_{c c}$; the observed failure mode; the jacket confining effectiveness in terms of strength, $f_{c c} / f_{c o}$ (the ratio of the peak stress sustained by the confined concrete cylinder divided by the concrete-only strength of the control cylinder at ambient temperature); and the effectiveness of TRM vs FRP jackets in terms of strength, $f_{c c} / f_{c c, R}$.

\subsection{Unconfined concrete cylinders tests}

Six unwrapped (plain) concrete cylinders were tested. Two were tested to define ambient strength, and the remaining four were tested at selected elevated temperatures $\left(100{ }^{\circ} \mathrm{C}, 150{ }^{\circ} \mathrm{C}, 200{ }^{\circ} \mathrm{C}\right.$ and $\left.400{ }^{\circ} \mathrm{C}\right)$ in order to assess the effects of elevated temperature on the strength and stiffness of the unconfined concrete; such that any strength reductions observed

Table 2 Summary of test results of both TRM and FRP coupons

\begin{tabular}{llll}
\hline & Ultimate tensile strength, $f_{f u}(\mathrm{MPa})$ & Ultimate tensile strain, $\varepsilon_{f u}(\%)$ & Modulus of elasticity, $\boldsymbol{E}_{f_{-}}(\mathrm{GPa})$ \\
\hline TRM coupons & $1545(132)$ & $0.798(0.095)$ & $182.6(21)$ \\
FRP coupons & $2802(76)$ & $1.314(0.11)$ & $213.3(16)$ \\
\hline
\end{tabular}


Fig. 5 Ultimate compressive strength versus temperature

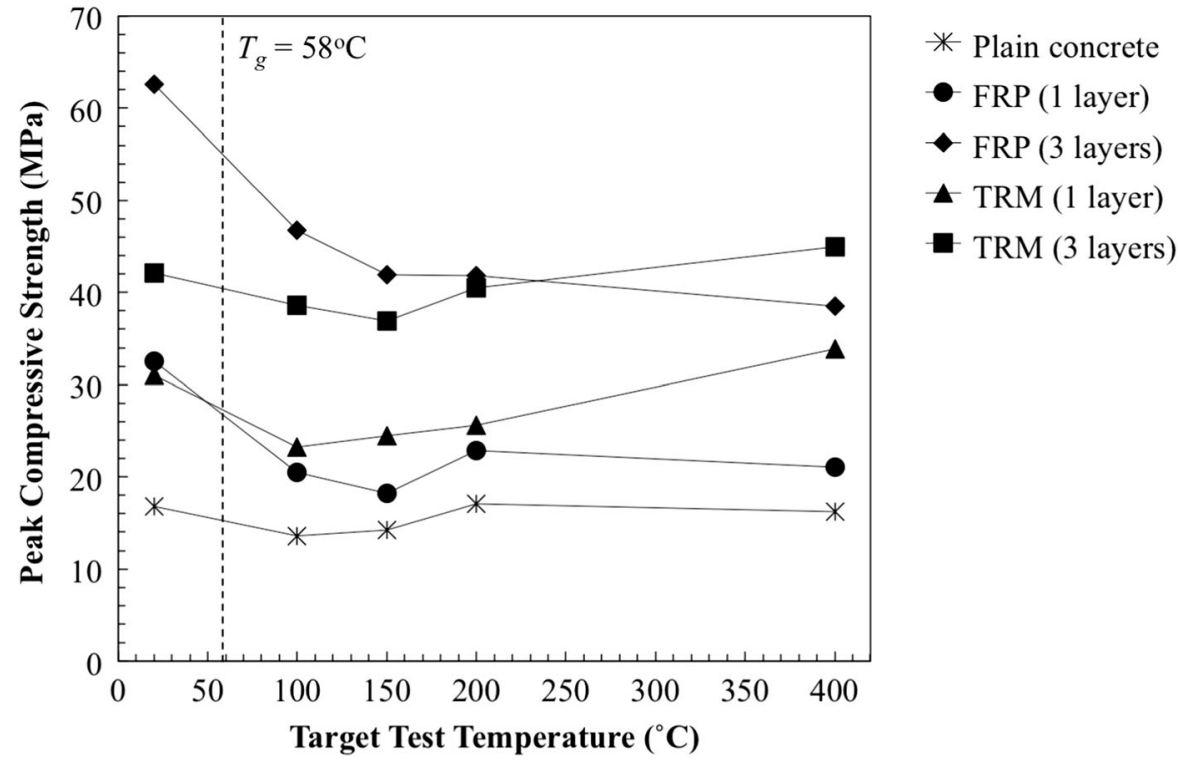

for the FRP and TRM confined specimens could be attributed to reductions in the effectiveness of the confining mechanism. The average ambient unwrapped concrete strength was $16.1 \mathrm{MPa}$. The concrete strength was reduced slightly, by $15 \%$ and $12 \%$ at $100{ }^{\circ} \mathrm{C}$ and $150{ }^{\circ} \mathrm{C}$, respectively, before recovering to a strength $5 \%$ above that at ambient at $200{ }^{\circ} \mathrm{C}$. At $400{ }^{\circ} \mathrm{C}$ there was no obvious reduction in compressive strength. In addition the failure mode of unwrapped concrete cylinders was not affected from their exposure at elevated temperature, as shown in Fig. 6a and b. Whilst it is difficult to draw definitive conclusions regarding the effects of elevated temperature exposure on the plain concrete cylinders due to the small number of specimens tested, it is noteworthy both that these test data contradict the widely accepted concrete strength reductions with temperature suggested in the Structural Eurocodes [38]—which indicates an expected compressive strength reduction of between 15 and $20 \%$ at $400{ }^{\circ} \mathrm{C}$, depending on the aggregate mineralogy - and that similar strength trends seem to underlie the responses of the FRP and TRM confined specimens (discussed below). The lack of reduction in compressive strength of the concrete at $400{ }^{\circ} \mathrm{C}$ suggests that additional research is warranted in this area.

\subsection{Tests on FRP confined concrete}

Figure 5 and Table 3 show a clear trend of reducing FRP confined concrete strength with increased steady state exposure temperature; although with such a small number of samples it is difficult to clearly distinguish if this is attributed to concrete thermal damage effects and/or loss of FRP confinement effects. Whilst the results for FRP confined cylinders are similar to those previously reported by Rickard et al. [5], additional testing with a larger number of cylinders will be required to have greater statistical confidence in the results obtained.

It is clear that exposure temperatures above $T_{g}$ cause considerable reductions in the strength of FRP confined concrete cylinders. It is also clear, however, as previously reported by Rickard et al. [5], that the FRP wrap provided considerable additional strength at all temperatures tested, particularly for the case with three continuous layers of carbon fibre reinforcement. For the case of three layers of FRP, the confinement continued to enhance the failure strength at temperatures well above $T_{g}$. For example, strength was enhanced by more than $200 \%$ at $400{ }^{\circ} \mathrm{C}$. The confinement provided by the single layer of FRP is considerably less; this is likely the result of frictional bond strength for the three layer wrapping, which is able to provide confinement even once the adhesive has lost the majority of its mechanical properties. 
Table 3 Summary of test results

\begin{tabular}{|c|c|c|c|c|c|c|c|c|c|}
\hline \multirow[t]{2}{*}{ No. } & \multirow[t]{2}{*}{ Wrapping } & \multirow[t]{2}{*}{$\begin{array}{l}\text { Target exposure temp. } \\
\left({ }^{\circ} \mathrm{C}\right)\end{array}$} & \multicolumn{2}{|c|}{$\begin{array}{l}\text { Temp. at } \\
\text { failure }\left({ }^{\circ} \mathrm{C}\right)\end{array}$} & \multirow[t]{2}{*}{$\begin{array}{l}\text { Peak load } \\
(\mathrm{kN})\end{array}$} & \multirow[t]{2}{*}{$\begin{array}{l}\text { Peak stress, } f_{c c} \\
(\mathrm{MPa})\end{array}$} & \multirow[t]{2}{*}{$\begin{array}{l}\text { Failure } \\
\text { mode* }\end{array}$} & \multirow[t]{2}{*}{$\begin{array}{l}f_{c c} \\
f_{c o}\end{array}$} & \multirow[t]{2}{*}{$\begin{array}{l}f_{c d} \\
f_{c c, R}\end{array}$} \\
\hline & & & Air & Surface & & & & & \\
\hline 1 & \multirow[t]{6}{*}{-} & 20 & 20 & 20 & 132.0 & 16.1 & - & 1 & NA \\
\hline 2 & & & 20 & 20 & 121.2 & & - & & \\
\hline 3 & & 100 & 99 & 96 & 107.2 & 13.6 & - & 1 & NA \\
\hline 4 & & 150 & 150 & 139 & 111.4 & 14.2 & - & 1 & NA \\
\hline 5 & & 200 & 200 & 189 & 134.3 & 17.1 & - & 1 & NA \\
\hline 6 & & 400 & 400 & 362 & 127.3 & 16.2 & - & 1 & NA \\
\hline 7 & \multirow{6}{*}{$\begin{array}{l}\text { Single layer of } \\
\text { FRP }\end{array}$} & 20 & 20 & 20 & 255.1 & 32.5 & Rupture & 2.02 & 1 \\
\hline 8 & & 80 & 76 & 74 & 220.2 & 28.0 & Rupture & NA & NA \\
\hline 9 & & 100 & 94 & 93 & 161.1 & 20.5 & Mixed & 1.27 & 1 \\
\hline 10 & & 150 & 148 & 145 & 142.6 & 18.2 & Mixed & 1.13 & 1 \\
\hline 11 & & 200 & 196 & 186 & 179.6 & 22.9 & Adhesive & 1.42 & 1 \\
\hline 12 & & 400 & 394 & 370 & 165.6 & 21.1 & Adhesive & 1.31 & 1 \\
\hline 13 & \multirow{6}{*}{$\begin{array}{l}\text { Single layer of } \\
\text { TRM }\end{array}$} & 20 & 20 & 20 & 243.1 & 31.0 & Rupture & 1.92 & 0.95 \\
\hline 14 & & 100 & 94 & 93 & 182.3 & 23.2 & Rupture & 1.44 & 1.13 \\
\hline 15 & & 150 & 146 & 143 & 192.8 & 24.5 & Mixed & 1.52 & 1.35 \\
\hline 16 & & 200 & 195 & 186 & 201.4 & 25.6 & Rupture & 1.59 & 1.12 \\
\hline 17 & & 400 & 377 & 369 & 266.4 & 31.5 & Mixed & 1.95 & 1.49 \\
\hline 18 & & & 386 & 375 & 227.5 & & Rupture & & \\
\hline 19 & \multirow{6}{*}{$\begin{array}{l}\text { Three layers of } \\
\text { FRP }\end{array}$} & 20 & 20 & 20 & 491.6 & 62.8 & Rupture & 3.89 & 1 \\
\hline 20 & & & 20 & 20 & 494.0 & & Rupture & & \\
\hline 21 & & 100 & 93 & 91 & 367.4 & 46.8 & Rupture & 2.90 & 1 \\
\hline 22 & & 150 & 147 & 139 & 328.9 & 41.9 & Mixed & 2.60 & 1 \\
\hline 23 & & 200 & 195 & 188 & 328.1 & 41.8 & Adhesive & 2.59 & 1 \\
\hline 24 & & 400 & 384 & 371 & 302.2 & 38.5 & Adhesive & 2.39 & 1 \\
\hline 25 & \multirow{6}{*}{$\begin{array}{l}\text { Three layers of } \\
\text { TRM }\end{array}$} & 20 & 20 & 20 & 330.5 & 42.1 & Rupture & 2.61 & 0.67 \\
\hline 26 & & 100 & 93 & 89 & 303.1 & 38.6 & Mixed & 2.39 & 0.82 \\
\hline 27 & & 150 & 146 & 141 & 290.1 & 36.9 & Rupture & 2.29 & 0.88 \\
\hline 28 & & 200 & 194 & 186 & 317.8 & 40.5 & Rupture & 2.51 & 0.97 \\
\hline 29 & & 400 & 396 & 371 & 353.7 & 45 & Mixed & 2.79 & 1.17 \\
\hline 30 & & & 383 & 362 & 353.1 & & Mixed & & \\
\hline
\end{tabular}

*'Rupture' refers to failure by tensile rupture of the confining material in the hoop direction, 'Adhesive' refers to failure by within the adhesive layer, and 'Mixed' refers failure by a combination of rupture and adhesive failures

Both specimens with one and three FRP layers failed due to rupture of FRP jacket at ambient temperature as shown in Fig. $6 \mathrm{c}$ and d. The same failure mode was observed in all FRP confined cylinders tested up to $80{ }^{\circ} \mathrm{C}$ and $100{ }^{\circ} \mathrm{C}$. FRP confined cylinders tested at $150{ }^{\circ} \mathrm{C}$ failed due to a mixed failure mode including both fibre rupture and adhesive failure, as shown in Fig. 6e, whereas the failure of cylinders tested at temperature above $150{ }^{\circ} \mathrm{C}$ was attributed to adhesive failure due to softening or decomposition of epoxy resin (Fig. 6f).

\subsection{Tests on TRM confined concrete}

For the TRM confined concrete cylinders, Fig. 5 and Table 3 show that the TRM system was marginally 


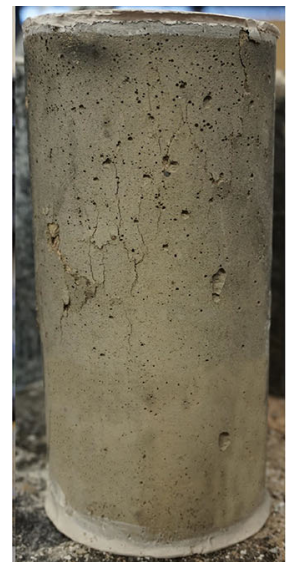

(a)

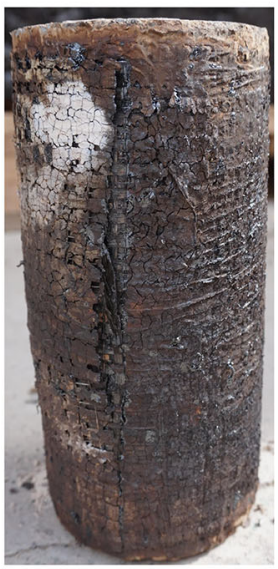

(f)

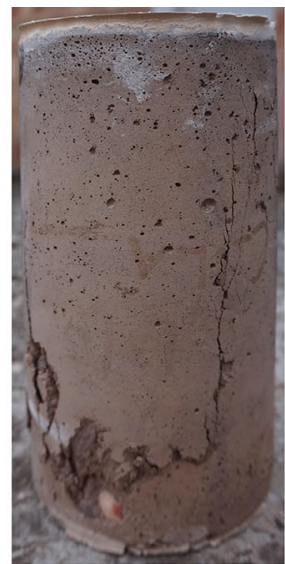

(b)

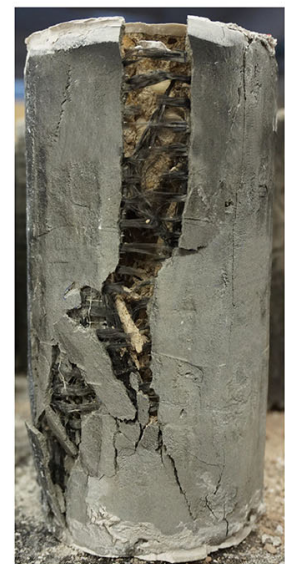

(g)

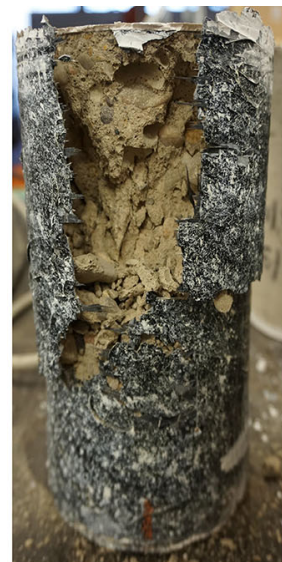

(c)

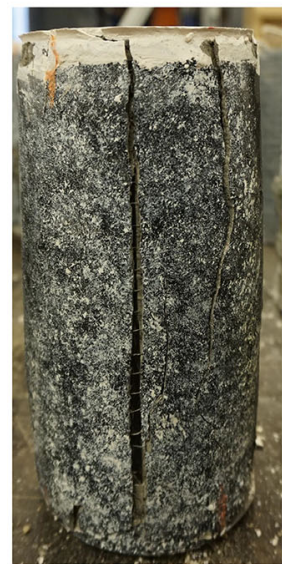

(h)

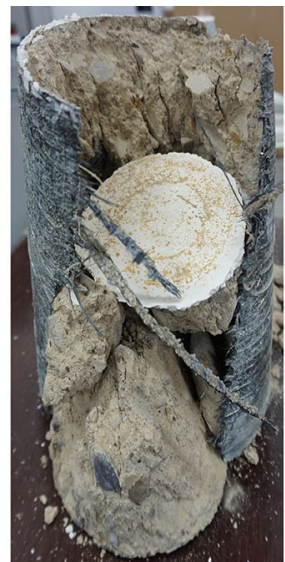

(d)

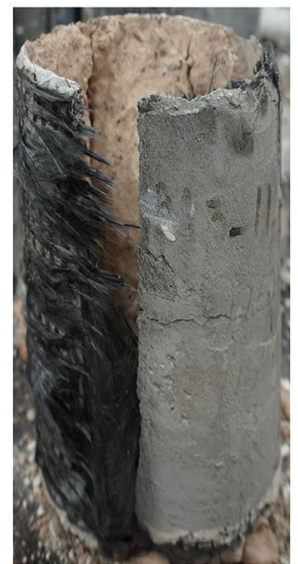

(i)

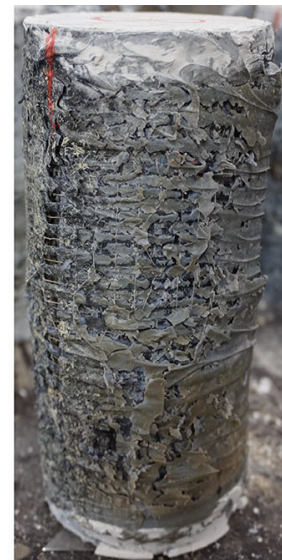

(e)

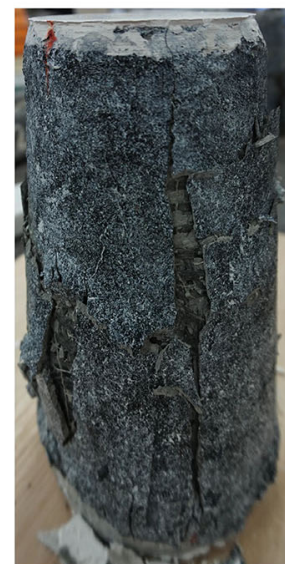

(j)
Fig. 6 Failure modes of tested specimens: a control specimen at ambient temperature; b control specimen at $400{ }^{\circ} \mathrm{C}$; c single layer of FRP at ambient temperature; $\mathbf{d}$ three layers of FRP at ambient temperature; e single layer of FRP at $400{ }^{\circ} \mathrm{C}$; $\mathbf{f}$ three

less effective than the FRP system for a single layer at ambient conditions, and that its performance was similarly affected by exposure to a temperature of $100{ }^{\circ} \mathrm{C}$, losing $23 \%$ of its strength at this temperature. This is likely due to a combination of reductions in the strength of the concrete itself at this temperature (discussed previously) and the strengthening mortar (see Fig. 1b) combined with reductions in the effectiveness of the confinement (for reasons which remain unknown). Failure of the cylinder that received a single TRM layer was due to rupture of TRM jacket, as shown in Fig. 6g. However, at temperatures above $100{ }^{\circ} \mathrm{C}$ the TRM system recovered its strength more rapidly than either the plain or FRP confined layers of FRP at $400{ }^{\circ} \mathrm{C} ; \mathbf{g}$ single layer of TRM at ambient temperature; $\mathbf{h}$ single layer of TRM at $400{ }^{\circ} \mathrm{C}$; $\mathbf{i}$ three layers of TRM at $400{ }^{\circ} \mathrm{C}$; $\mathbf{j}$ three layers of TRM at $400{ }^{\circ} \mathrm{C}$

specimens, and at $400{ }^{\circ} \mathrm{C}$ the single layer TRM confined sample tested stronger than its counterpart sample at ambient temperature. Failure of single layer TRM cylinders at elevated temperatures was attributed to rupture of the TRM jacket in hoop tension in most cases (Fig. 6h), whereas the failure of some TRM confined cylinders was attributed to combined rupture with adhesive failure (i.e. at $150{ }^{\circ} \mathrm{C}$ ).

Similar observations can be made regarding the performance of the three layer TRM confining system. In this case the strengthening provided by the TRM system was considerably less, by $33 \%$, than the three layer FRP system, probably because of differences in the observed failure mode-tensile pull-out of the 
fibres from the cementitious matrix followed by partial fibre fracture in the case of the TRM, compared with tensile fibre fracture over the height of the cylinder in the case of the FRP. Failure of the TRM wrapped specimens was considerably less violent than for the FRP wrapped cylinders, and these absorbed more energy than for the FRP wrapped specimens, particularly at lower temperatures. This may present advantages particularly in seismic strengthening applications.

However, at elevated temperature the three layer TRM system displayed similar response as for the single layer TRM system, with mild reductions in strength at 100,150 , and $200{ }^{\circ} \mathrm{C}$ (likely for the reasons discussed in the previous paragraph), but a small increase (by 7\%) in strength at $400{ }^{\circ} \mathrm{C}$ as compared with the strength at ambient. At elevated temperatures failure of cylinders wrapped with three TRM layers was attributed either to rupture of the TRM jacket (Fig. 6i), or to a combined rupture with adhesive failure, as shown in Fig. 6j.

Increases in the effectiveness of the TRM system at elevated temperature are striking, particularly for the case of the three-layer TRM system, and may be due to thermal prestressing of the carbon fibres during heating, as has previously been suggested by Rickard et al. [5] for multiple layer FRP confining systems at elevated temperature. Since carbon fibres generally have a slightly negative coefficient of thermal expansion, whereas the concrete core has a positive coefficient of thermal expansion, thermal dilation of the concrete core during heating will develop tensile stresses in the carbon fibre mesh, and provided that bond is maintained (either by adhesion or by winding friction) the wrap will self-prestress, which can be expected the enhance both the strength and stiffness of the TRM confined cylinders. This hypothesis warrants additional research and may indicate that unprotected TRM systems are capable of providing effective (i.e. active) confinement of concrete at temperatures up to and exceeding $400{ }^{\circ} \mathrm{C}$ (something that epoxy-based FRP systems are less able to do). It should be also mentioned that, based on Fig. 1b, both the flexural and compressive strength of mortar at temperatures ranging between $100{ }^{\circ} \mathrm{C}$ and $400{ }^{\circ} \mathrm{C}$ follow a similar trend with that of the cylinder compressive strength (Fig. 5). Specifically, the mortar flexural strength at ambient temperature was $8.64 \mathrm{MPa}$ and but decreased when the mortar was exposed to both $100{ }^{\circ} \mathrm{C}(2.70 \mathrm{MPa})$ and $150{ }^{\circ} \mathrm{C}(2.12 \mathrm{MPa})$. At $250{ }^{\circ} \mathrm{C}$, however, the mortar's strength started increasing (2.55 MPa), recovering to $3.03 \mathrm{MPa}$ at $400{ }^{\circ} \mathrm{C}$.

\subsection{Axial/hoop stress versus strain response}

Typical stress-strain curves obtained during steady state testing using the image correlation analysis are given in Fig. 7. It was challenging to obtain consistent strain information during these tests due to thermal effects on the image correlation technique; the results should therefore be taken as only indicative of the response. It is noteworthy that both the strength and stiffness of the confined concrete appear to be significantly reduced at $150{ }^{\circ} \mathrm{C}$, whereas these appear to be recovered at $400{ }^{\circ} \mathrm{C}$. Again, this behaviour
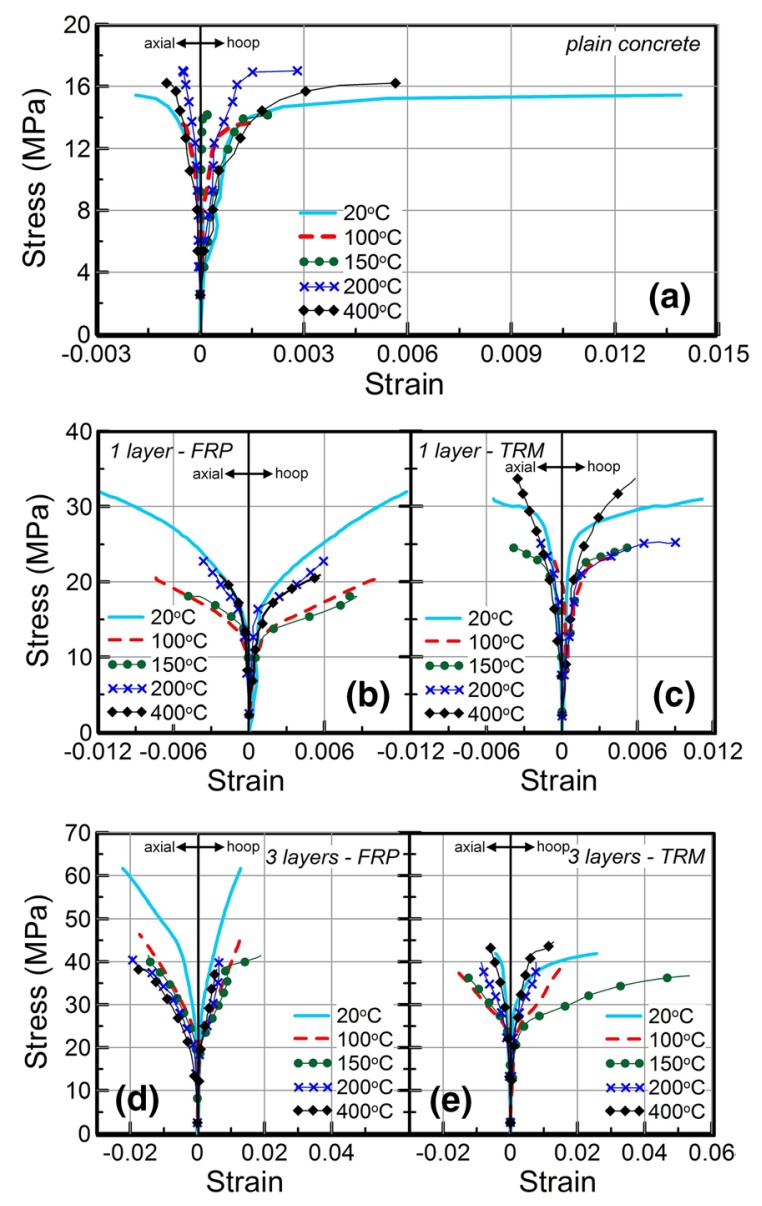

Fig. 7 Stress-strain curves for: a plain concrete cylinders; b cylinders with one FRP layer; c cylinders with one TRM layer; d cylinders with three FRP layers and e cylinders with three TRM layers 
warrants further investigation, both for confinement research but also for structural fire engineering research focusing on concrete structures.

\subsection{TRM vs FRP confining effectiveness}

The confining effectiveness in terms of strength, $f_{c c} / f_{c o}$ is given in Table 3. By comparing the response of confined cylinders with that of unjacketed ones, it is concluded that both FRP and TRM confinement is effective in increasing the capacity of plain concrete cylinders. The effectiveness in terms of strength $\left(f_{c c} l\right.$ $f_{c o}$ ) was approximately 1.92 for a single layer of TRM or 2.02 for a single FRP layer at ambient temperature. Confinement effectiveness decreased with increasing temperature. The single FRP layer had its minimum effectiveness $\left(f_{c c} / f_{c o}\right)$ at $150{ }^{\circ} \mathrm{C}(1.13)$, whereas for the single TRM layer this occurred at $100{ }^{\circ} \mathrm{C}$ (1.44). In case of three layers, at ambient temperature, the $f_{c c} / f_{c o}$ values were 3.89 and 2.61 for FRP and TRM jacketing, respectively. The minimum jacket confining effectiveness for three FRP layers was 2.39 at $400{ }^{\circ} \mathrm{C}$, whereas the corresponding value for the equivalent TRM system was 2.29 at $150{ }^{\circ} \mathrm{C}$ (with subsequent effectiveness recovery as already discussed).

A comparison of the effectiveness of mortar-based jackets to that of resin-based jackets is given by dividing their effectiveness. In terms of strength this is expressed by the ratio $f_{c c} / f_{c c, R}$ (see Table 3 ). For a lesser amount of reinforcement (i.e. a single carbon fibre layer) the effectiveness of TRM and FRP was almost equal $\left(f_{c c} / f_{c c, R}=0.95\right)$ at ambient temperatures, while at temperatures ranging between $100-200{ }^{\circ} \mathrm{C}$, the TRM confinement became progressively more effective than FRP $\left(f_{c c} / f_{c c, R}=0.95\right.$ ranges from 1.13 to 1.35). At $400{ }^{\circ} \mathrm{C}$ TRM was found 1.5 times more effective than FRP in terms increasing the cylinders strength. For higher amount of confinement reinforcement (i.e. 3 carbon fibre layers), the confining effectiveness of TRM was considerably lower than FRP jacketing at ambient temperatures $\left(f_{c c} / f_{c c, R}=-\right.$ 0.67). However as can been observed in Table 3, the ratio $f_{c c} / f_{c c, R}$ is increasing with the temperature in an almost proportional manner, with recorded values equal to $0.82,0.88,0.97$ and 1.17 for $100{ }^{\circ} \mathrm{C}, 150{ }^{\circ} \mathrm{C}$, $200^{\circ}$ and $400{ }^{\circ} \mathrm{C}$, respectively.

\section{Conclusions}

The following conclusions can be drawn on the basis of the tests reported herein:

- Considerable loss of effectiveness of the FRP wrap system occurred at temperatures exceeding the $T_{g}$ of the epoxy adhesive used. This is thought to be due to reductions in the tensile, and more importantly bond, strength and stiffness of the FRP wraps at these temperatures.

- The ultimate load capacity of FRP wrapped cylinders continued to decrease with increasing temperatures; however, the FRP wrap continued to provide some confinement at all exposure temperatures, both for a single layer and for a triple layer, even at $400{ }^{\circ} \mathrm{C}$ which is well above $T_{g}$. This is possibly attributed to bond retention resulting from winding friction, which appears to be (as expected), much more effective for three continuous layers of FRP than for a single layer.

- FRP rupture was the observed failure mode at temperatures below $100{ }^{\circ} \mathrm{C}$; above $100{ }^{\circ} \mathrm{C}$ the failure mode was observed to transition to bond failure in the FRP overlapping zone.

- Minor loss of effectiveness of the TRM wrap system occurred at temperatures between 100 and $200{ }^{\circ} \mathrm{C}$. This is thought to be due to reductions in the compressive strength of the concrete at these temperatures (as corroborated by compression tests on unconfined concrete at these temperatures). However, both single and triple layer TRM wrap systems demonstrated enhanced strength at $400{ }^{\circ} \mathrm{C}$.

- It appears that differential thermal expansion between the carbon fibre reinforced wraps (contracting) and the concrete column (expanding) caused a slight prestress of the FRP and TRM systems during heating.

- The number of FRP and TRM layers of wrapping (hence the effective overlap length used) had a significant impact on the confinement effectiveness at elevated temperature; however, additional testing is required to study the influence of wrapping with multiple continuous layers on the performance of FRP and TRM confined concrete at elevated temperature. 


\section{Recommendations}

The following are recommendations for future work in this area:

- Further tests on unconfined concrete at elevated temperature are required to better understand the effects of heating (and heating rate) on reduction in unconfined concrete compressive strength.

- Additional repeat tests, particularly on FRP and TRM confined concrete, are required to ensure statistical confidence in the results obtained and to corroborate the results and hypotheses presented herein.

- Other available FRP and TRM wrap systems and materials need to be studied to allow any generalization of the observations made during the current study.

- Cylinders tested in this project were subjected to loads at elevated temperatures for relatively short periods of time. The potential effects of prolonged loading and heating, as might occur in warm service temperatures, require study since creep may cause failure at lower temperatures under long term loading.

- Additional tests should be conducted on FRP and TRM confined RC columns at full-scale, including internal steel reinforcement as would almost certainly exist in practice.

Acknowledgements The third author acknowledges the JRC Exploratory Research Programme, Project iRESIST+, Joint Research Centre, European Commission. The authors gratefully acknowledge the assistance of Dr Saad Raoof in the specimens' preparation.

\section{Compliance with ethical standards}

Conflict of interest The authors declare that they have no conflict of interest.

Open Access This article is licensed under a Creative Commons Attribution 4.0 International License, which permits use, sharing, adaptation, distribution and reproduction in any medium or format, as long as you give appropriate credit to the original author(s) and the source, provide a link to the Creative Commons licence, and indicate if changes were made. The images or other third party material in this article are included in the article's Creative Commons licence, unless indicated otherwise in a credit line to the material. If material is not included in the article's Creative Commons licence and your intended use is not permitted by statutory regulation or exceeds the permitted use, you will need to obtain permission directly from the copyright holder. To view a copy of this licence, visit http://creativecommons.org/licenses/by/4.0/.

\section{References}

1. Bisby LA, Chen JF, Li SQ, Stratford TJ, Cueva N, Crossling K (2011) Strengthening fire-damaged concrete by confinement with fibre-reinforced polymer wraps. Eng Struct 33(12):3381-3391

2. Chowdhury E, Eedson R, Green M, Bisby L, Benichou N (2011) Mechanical characterization of fibre reinforced polymers materials at high temperature. Fire Tech 47:1063-1080

3. ACI (2008) 440.2R-08 Guide for the design and construction of externally bonded FRP systems for strengthening concrete structures. American Concrete Institute, Farmington Hills, MI

4. Chowdhury E, Bisby L, Green M, Kodur V (2007) Investigation of insulated FRP-wrapped reinforced concrete columns in fire. Fire Saf J 42:452-460

5. Rickard I, Bisby L, Stratford T, Hulsberg S (2013) Effects of heating on FRP confinement of concrete. In: 11th International symposium on fibre reinforced polymers for reinforced concrete structures, Guimarães, Portugal, 26-28 June

6. Koutas LN, Tetta Z, Bournas DA, Triantafillou TC (2019) Strengthening of concrete structures with textile reinforced mortars: state-of-the-art review. J Compos Constr 23:03118001. https://doi.org/10.1061/(ASCE)CC.19435614.0000882

7. Carloni C, Bournas DA, Carozzi FG, D’Antino T, Fava G, Focacci F, Giacomin G, Mantegazza G, Pellegrino C, Perinelli C, Poggi C (2015) Fiber reinforced composites with cementitious (inorganic) matrix. In: Pellegrino C, SenaCruz J (eds) Chapter 9 in: Design procedures for the use of composites in strengthening of reinforced concrete structures-State of the art report of the RILEM TC 234-DUC. RILEM STAR Book Series, vol 501. Springer, Berlin, pp 349-391

8. Koutas L, Bournas DA (2016) Flexural strengthening of two-way RC slabs with textile-reinforced mortar: experimental investigation and design equations. J Compos Constr. https://doi.org/10.1061/(ASCE)CC.1943-5614.0000713

9. Papanicolaou CG, Triantafillou TC, Papathanasiou M, Karlos K (2008) Textile-reinforced mortar (TRM) versus FRP as strengthening material of URM walls: out-of-plane cyclic loading. Mater Struct 41:143-157

10. Raoof SM, Koutas LN, Bournas DA (2016) Bond between textile-reinforced mortar (TRM) and concrete substrates: experimental investigation. Compos B 98:350-361. https:// doi.org/10.1016/j.compositesb.2016.05.041

11. Tetta ZC, Koutas LN, Bournas DA (2015) Textile-reinforced mortar (TRM) versus fibre-reinforced polymers (FRP) in shear strengthening of concrete beams. Compos Part B 77:338-348. https://doi.org/10.1016/j.compositesb. 2015.03.055

12. Tetta ZC, Koutas LN, Bournas DA (2016) Shear strengthening of full-scale RC T-beams using textile-reinforced mortar and textile-based anchors. Compos Part B 
2016(95):225-239. https://doi.org/10.1016/j.compositesb. 03.076

13. Triantafillou TC, Papanicolaou CG (2006) Shear strengthening of reinforced concrete members with textile reinforced mortar (TRM) jackets. Mater Struct Rilem 39(1):85-93

14. Triantafillou TC, Papanicolaou CG, Zissimopoulos P, Laourdekis $T$ (2006) Concrete confinement with textilereinforced mortar jackets. ACI Struct J 103(1):28-37

15. Bournas DA, Lontou PV, Papanicolaou CG, Triantafillou TC (2007) Textile-reinforced mortar versus fibre-reinforced polymer confinement in reinforced concrete columns. ACI Struct J 104(6): 1

16. Bournas DA, Triantafillou TC, Zygouris K, Stavropoulos F (2009) Textile-reinforced mortar versus FRP Jacketing in seismic retrofitting of RC columns with continuous or Lapspliced deformed bars. J Comp Constr 13(5):360-371

17. Bournas DA (2018) Concurrent seismic and energy retrofitting of RC and masonry building envelopes using inorganic textile-based composites combined with insulation materials: a new concept. Compos Part B Eng 148:166-179

18. Gkournelos PD, Bournas DA, Triantafillou TC (2019) Combined seismic and energy upgrading of existing reinforced concrete buildings using TRM jacketing and thermal insulation. Earthq Struct 16:625-639. https://doi.org/10. 12989/EAS.2019.16.5.625

19. Pohoryles DA, Maduta C, Bournas DA, Kouris LA (2020) Energy performance of existing residential buildings in Europe: a novel approach combining energy with seismic retrofitting. Energy Build (in press)

20. Triantafillou TC, Karlos K, Kefalou K, Argyropoulou E (2017) An innovative structural and energy retrofitting system for URM walls using textile reinforced mortars combined with thermal insulation: mechanical and fire behavior. Constr Build Mater 133:1-13. https://doi.org/10. 1016/j.conbuildmat.2016.12.032

21. Al-Salloum YA, Almusallam TH, Elsanadedy HM, Iqbal RA (2016) Effect of elevated temperature environments on the residual axial capacity of RC columns strengthened with different techniques. Constr Build Mater 115:345-361

22. Askouni PD, Papanicolaou CCG, Kaffetzakis MI (2019) The effect of elevated temperatures on the TRM-to-masonry bond: comparison of normal weight and lightweight matrices. Appl Sci Basel 9:2156

23. Donnini J, Corinaldesi V, Nanni A (2016) Mechanical properties of FRCM using carbon fabrics with different coating treatments. Compos Part B Eng 88:220-228. https:// doi.org/10.1016/j.compositesb.2015.11.012

24. Kapsalis P, El Kadi M, De Vervloet J, Munck M, Wastiels J, Triantafillou T, Tysmans T (2019) Thermomechanical behavior of textile reinforced cementitious composites subjected to fire. Appl. Sci. 9:747

25. Maroudas SR, Papanicolaou CG (2017) Effect of high temperatures on the TRM-to-masonry bond. Key Eng Mater 747:533-554
26. Messori M, Nobili A, Signorini C, Sola A (2019) Effect of high temperature exposure on epoxy-coated Glass Textile Reinforced Mortar composites. Constr Build Mater 212:765-774

27. Tlaiji T, Vu XH, Ferrier E, SiLarbi A (2018) Thermomechanical behaviour and residual properties of textile reinforced concrete (TRC) subjected to elevated and high temperature loading: experimental and comparative study. Compos Part B Eng 144:99-110. https://doi.org/10.1016/j. compositesb.2018.02.022

28. Truong GT, Kim J, Choi K-K (2018) Effect of multi-walled carbon nanotubes (MWCNTs) and electroless copper plating on tensile behavior of carbon fiber reinforced polymers. Adv Mater Sci Eng 1:1. https://doi.org/10.1155/2018/ 8264138

29. Bisby L, Stratford T, Hart C, Farren S (2013) Fire performance of well-anchored TRM, FRCM, and FRP flexural strengthening systems. Advanced Composites in Construction 2013

30. Tetta ZC, Bournas DA (2016) TRM versus FRP jacketing in shear strengthening of concrete members: behaviour at high temperature. Compos Part B: Eng 106:190-205

31. Raoof SM, Bournas DA (2017) Bond between TRM versus FRP composites and concrete at high temperatures. Compos Part B Eng 127:150-165. https://doi.org/10.1016/j. compositesb.2017.05.064

32. Raoof SM, Bournas DA (2017) TRM versus FRP in flexural strengthening of RC beams: behaviour at high temperatures. Compos Part B Eng 154:424-437. https://doi.org/10.1016/j. conbuildmat.2017.07.195

33. EN 1015-11 (1993) Methods of test for mortar for masonry-Part 11: Determination of flexural and compressive strength of hardened mortar, Brussels: Comité Européen de Normalisation

34. Saafi M (2002) Effect of fire on FRP reinforced concrete members. Compos Struct 58:11-20

35. Signorini C, Signorini A, Nobili A, Sola A, Messoric M (2020) Designing epoxy viscosity for optimal mechanical performance of coated Glass Textile Reinforced Mortar (GTRM) composites. Constr Build Mater 233:117325

36. White D, Take WA, Bolton M (2003) Soil deformation measurement using particle image velocimetry (PIV) and photogrammetry. Geotechnique 53:619-631

37. Tetta ZC, Koutas LN, Bournas DA (2018) Shear strengthening of concrete members with TRM jackets: effect of shear span-to-depth ratio, material and amount of external reinforcement. Compos Part B Eng 137:184-201

38. CEN (2004) EN 1992-1-2:2004 Eurocode 2: Design of concrete structures-Part 1-2: General rules-Structural fire design. European Committee for Standardisation, Brussels

Publisher's Note Springer Nature remains neutral with regard to jurisdictional claims in published maps and institutional affiliations. 